\title{
PENDIDIKAN MORAL MASYARAKAT JAWA \\ (Studi Nilai-Nilai Pendidikan Moral dalam \\ Tradisi Ruwatan)
}

Oleh: Muzhoffar Akbwan, Suyanto, Mubammad Roy *

Abstract

This article aims to describe the ruwatan concepts as a part of the Javanese traditions in the form of educational values. 'Ruwatan' is often claimed as a negative tradition that tends to polytheism. However, the fact indicates that ruwatan is still existing in Javanese society tradition until recent ages.

Based on the condition, the article tries to explain the positive meaning of ruwatan. Since it has positive meaning, the ruwatan is necessary to preserve. In the tradition, it contains one of moral education methods to educate society in order to make better human beings. The study found some educational values in the tradition, i.e. teological education, philosophical education, and social education.

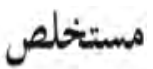

يهذف هذا البحث إلى استجلاء أبعاد مفهوم "رواتان" كأحد التقاليد ذات العلاقة بالقيم التربوية في الجتمع الجاويّ الإندونيسي. ينظر البعض إلى هذا التقليد المتأصل في البيئة الاجتماعية الجاوية باغتباره

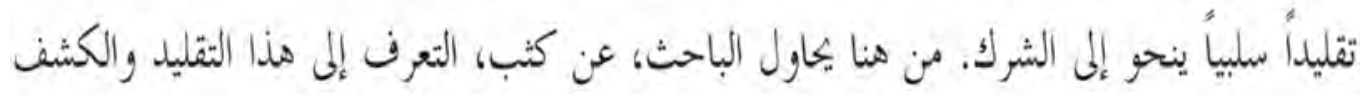
عن المعائ الإيجابية الكامنة به (إن وجلدت). ولقد انتهى البحث إلى أن هذا التقليد به من الأبعاد التربوية الإيحابية ما ينبغي الحفاظ عليها، مثل التربية العقائدية، والتربية الفلسفية، والتربية الاجتماعية. Keywords: Ruwatan, Pendidikan Moral, dan Sukerto

*Tim peneliti FIAI UII. Email: muzhofar@yahoo.com; suyanto_uii@yahoo.co.id; muh_roy@yahoo.com. 


\section{A. Pendahuluan}

Ruwatan merupakan peninggalan salah satu sisi kehidupan masyarakat Jawa yang diadatkan (menjadi tradisi) karena di anggap sakral. Kata ruwat sudah lama hidup dan ditemukan dalam karyasastra Jawa kuno, misalnya dalam kitab Ramayana yang ditulis pada zaman Mataram kuno, sekitar abad kesepuluh. Kata ruwat artinya "lepas". ${ }^{1}$ Kata angruwat atau rumuwat artinya membebaskan, exercise, misalnya membebaskan seseorang dari roh jahat. Sering juga berarti "membebaskan, melepaskan, menyelamatkan". Kata rinuwat artinya "dibebaskan, dilepaskan, diselamatkan".2

Ruwatan adalah upacara yang dilakukan seseorang untuk membebaskan (sukerto) dari nasib buruk dan ancaman malapetaka. Sukerto atau sesuker (rereged) adalah kelemahan tertentu yang dipercaya dapat mengundang datangnya malapetaka yang mengancam keberadaan dan kebahagiaan. Orang yang termasuk penyandang sukerto atau pembawa sial harus dihilangkan dengan cara diruwat. Jika tidak maka ia akan menjadi mangsa Bathara Kala, sehingga hidupnya selalu diliputi kesialan. ${ }^{3}$

Tradisi ruwatan, yang merupakan tradisi yang turun temurun dari masyarakat Jawa kuno, ${ }^{4}$ hingga kini masih banyak dijumpai dalam kehidupan masyarakat Jawa, khususnya masyarakat Yogyakarta. ${ }^{5}$ Fenomena maraknya ruwatan di kalangan muslimYogyakarta ini dapat dilihat di iklan koran-koran Yogyakarta yang

1 Mardiwarsito, Kamus Jawa Kuno-Indonesia, (Ende Flores: Nusa Indah, 1978), hal. 227.

2 Zoetmulder, Kalangwan, (Jakarta: Penerbit Djambatan, 1983), Old Javanese English Dictionary, (Shamanisme-Gravenhage-Martinus Nijhoff, 1982), hal. 1578.

$3 \quad$ Ibid. 467.

4 Bukti tradisi ruwatan ini masih mendominasi struktur berpikir masyarakat Jawa juga dapat dilihat di dunia akademik, yaitu pada Universitas Tujuh Belas Agustus (Untag) Surabaya yang menggelar tradisi ruwatan yang diikuti 30 keluarga. Panitia menjelaskan bahwa ruwatan dilakukan sebagai upaya sterilisasi psikologis. Meskipun dengan penjelasan yang agak berbeda, namun hal ini sudah menunjukkan betapa tradisi ruwatan tidak saja dilakukan oleh masyarakat Jawa di pelosok desa, tetapi juga oleh masyarakat akademik. "Untag Gelar Budaya Ruwatan”, Kompas, 17 April 2003.

Pada tarap tertentu bahkan dapat dikatakan bahwa tradisi ruwatan masih mendominasi struktur berpikir sebagian besar masyarakat Jawa, sehingga tradisi ini masih dilakukan dalam konteks mencegah maupun setelah terjadinya bencana. Sebagai contoh, Sutardjo Suryoguritno, Wakil Ketua DPR RI mengimbau Presiden Susilo Bambang Yudhoyono dan Wapres Yusuf Kalla menyelenggarakan ruwatan bumi agar bencana tidak terus-menerus melanda Indonesia, mengingat sejak keduanya menjadi Presiden dan Wakil Presiden, berbagai bencana terus mendera bangsa Indonesia. "DPR Desak Pemerintah Larang Pesta Tahun Baru”, Republika, Kamis, 30 Desember 2004. 
menawarkan ruwatan, khususnya di bulan Muharram (Suro). ${ }^{6}$ Koran-koran yang sering menampilkan iklan atau berita tentang ruwatan seperti Kedaulatan Rakyat, Merapi, Bernas, Posmo dan Meteor. Hampir setiap hari, selama bulan Muharrom (Suro) koran-koran ini memberitakan dan menawarkan tentang ruwatan. Hal ini karena diyakini bahwa bulan Suro (Jawa) adalah bulan yang wingit, angker (keramat). Oleh karenanya perlu diadakan ruwatan, agar manusia selamat dari berbagai bahaya.

Praktik ruwatan yang menyertakan kepercayaan adanya kelemahan (sukerto) pada diri manusia, dan juga kepercayaan adanya Bathara Kala sebagai sumber dan pemberi malapetaka, secara sekilas seakan bertentangan dengan tradisi Islam (musyrik) dan praktik yang tanpa makna. Namun ketika ditelaah lebih jauh, ternyata praktik ruwatan mempunyai nilai edukatif yang tinggi bagi masyarakat, terutama pendidikan moral. Ruwatan menjadi media untuk mendidik masyarakat agar mempunyai kesadaran kolektif, berbuat baik, bersedekah, memperhatikan kebersihan dan kelestarian lingkungan.

Nilai-nilai pendidikan moral ini bisa terlihat antara lain sebagai berikut. Pertama, orang yang membakar rambut dan tulang dianggap memiliki sukerto dan harus diruwat. Hal ini sebenarnya mengandung nilai pendidikan kepada masyarakat agar tidak menjalankan kebiasaan membakar rambut dan tulang karena mengandung polusi udara dan mengganggu kenyamanan lingkungan.

Kedua, orang yang mematahkan pipisan (batu gilasan jamu) dianggap mempunyai sial (sukerto). Ini mempunyai nilai pendidikan agar orang berhati-hati dalam menumbuk jamu dan jangan sampai tercampur karena akan membahayakan orang lain. Sikap hati-hati adalah aspek preventif agar tidak timbul bencana, dan sumber ketentraman jiwa.

Ketiga, anak laki-laki tunggal (ontang anting) termasuk golongan sukerto. Ini mempunyai maksud agar masyarakat tidak takut terhadap anak banyak. Sebab dalam pandangan orang jawa okeh anak, okeh rejeki. Selain itu, anak satu biasanya cenderung manja dan dimanjakan, oleh karenanya orang tua harus meruwatnya, yaitu dengan tidak memanjakannya. Ini merupakan bagian pendidikan moralitas kepada masyarakat.

Keempat, orang menebang pohon dengan tanpa mengganti menanam yang baru dianggap sukerto (sial) dan harus diruwat. Ini jelas memberikan pendidikan 
menghargai lingkungan hidup. Orang harus melestarikan lingkungan, dengan tidak menebang pohon sembarangan. ${ }^{7}$

Berdasarkan pada data awal sebagaimana diuraikan di atas, peneliti memiliki asumsi dasar bahwa terdapat nilai-nilai pendidikan moral yang tinggi pada tradisi Ruwatan. Ruwatan bukan hanya prosesi menghilangkan sukerto belaka, tetapi sebagai media mendidik masyarakat Jawa agar memiliki moralitas yang tinggi, dengan mengembangkan sikap gotong royong, toleransi, jujur, menghargai sesama, alam, dan lingkungan. Oleh karena itu, penelitian ini berusaha mengungkap lebih jauh nilai-nilai pendidikan (education values) moral pada tradisi ruwatan tersebut.

\section{B. Makna dan Nilai Pendidikan dalam Tradisi Ruwatan}

Tradisi ruwatan yang berkembang di Jawa dapat dimaknai dari berbagai macam tataran; tataran general, kategorisasi manusia sukerto (sengkala), prosesi ritual, dan sarana upacara yang dipergunakan.

\section{Pemaknaan Umum}

Secara umum, ruwatan dimaknai sebagai proses sterilisasi psikologis dari citra diri negatif yang terbangun oleh pola pikir orang yang bersangkutan. Secara psikologis, seperti apa seseorang akan sangat ditentukan bagaimana ia mencitrakan dirinya. Ketika yang dibangun adalah citra negatif, maka yang akan tampak dan menimpa dirinya adalah sesuatu negatif sesuai dengan pola pikir orang tersebut terhadap dirinya.

Selain makna di atas, menurut Syaiful Maghsri, ruwatan memiliki makna yang mendalam dari aspek spiritual, sosial, dan ritual. Dari aspek spiritual merupakan sarana hijrah dari posisi hati resah gelisah ke posisi tenang dan damai, dari posisi kehidupan yang sulit penuh rintangan ke posisi hidup yang penuh kemudahan, kesembuhan dan kesehatan. Sedang aspek sosial diharapkan memberikan makna terbebasnya seseorang dari persoalan hidup menuju hidup bahagia dan sejahtera. Adapun aspek ritual mendorong seseorang untuk lebih mendekatkan diri kepada Tuhan sebagai sumber pengendali kejadian, pengatur dan pemberi rahmat. ${ }^{8}$ hal. 60-63.

Lihat Suwardi Endraswara, Budi pekerti dalam Budaya Jawa, (Yogyakarta: Hanindita, 2003),

8 Wawancara 25 Desember 2007. 
Pemaknaan ruwatan dari aspek sosial yang agak berbeda diberikan oleh praktisi ruwatan lain, yaitu $\mathrm{Hj}$. Nunuk. Menurutnya, tradisi ruwatan sesungguhnya mendidik untuk seseorang memiliki jiwa sosial yang tinggi. Inti ajaran ruwatan menurutnya adalah upaya mendekatkan diri kepada Tuhan dan memperbaiki hubungan kepada sesama dengan cara bersedekah. "Umumnya, orang yang melaksanakan ruwatan adalah orang yang berlebih secara ekonomi. Upacara itu adalah untuk mengingatkan mereka untuk selalu ingat dan mengeluarkan sebagian rezekinya kepada masyarakat sekitar mereka yang hidupnya kurang beruntung. Prinsipnya jangan sampai ada yang mubazir dalam pelaksanaannya," ungkap Hj. Nunuk. Jadi, menurut Nunuk, ruwatan memiliki makna yang sangat tinggi dari aspek sosial karena berisi ajaran untuk bersedekah. ${ }^{9}$

\section{Pemaknaan Kategorisasi Sukerto(Sengkala)}

Sukerto ada dua macam, yaitu sukerto yang disandang manusia dan sukerto yang melekat pada lingkungan. Sukerto tersebut, baik yang melekat pada manusia maupun lingkungan hidup cara menghilangkannya harus dengan ruwatan. Jika tidak diruwat, orang atau lingkungan tersebut akan menjadi mangsa Bathara Kala, yaitu raksasa yang akan memakan dan menyengsarakan orang-orang yang mempunyai "kotoran" (sukerto) dan tidak dihilangkan melalui ruwatan.

Manusia sukerto adalah golongan orang-orang yang menurut kepercayaan dan gugon tuhon (keyakinan umum) dipandang sebagai penyandang sial sehingga keberadaan dan kebahagiaan hidupnya terancam. Sedangkan lingkungan sukerto adalah lingkungan seperti pekarangan, sawah, tegalan, hutan dan sebagainya yang secara langsung berhubungan dengan kehidupan manusia yang dipandang menyandang kelemahan atau kesialan sehingga menjadi ancaman bagi keberadaan dan kebahagiaan hidupnya.

Manusia penyandang sukerto pada dasarnya dapat dikelompokkan menjadi beberapa golongan berdasarkan kedudukan dan kelemahan masing-masing, yakni: pertama, golongan penyandang sukerto karena cacat bawaan, meliputi: (a) orang yang memiliki cacat tubuh sejak lahir, misalnya cebol, bungkik, cemani, bule, slewah dan sebagainya; (b) orang yang mempunyai kekhususan waktu kelahiran, misalnya julung pujud, julung wangi, julungsarab, dan julungsungsang; (c) orang yang mempunyai kekhususan dalam bersaudara, seperti pandhawa (lima laki-laki semua), pandhawi (lima perempuan semua), dhampit (lahir kembar laki-perempuan), ontang-

$9 \quad$ Wawancara 9 Januari 2008 . 
anting (anak semata wayang), kedhana-kedhini (dua orang bersaudara lakperempuan), kembar, sendang kapit pancuran (tiga bersaudara, tengah perempuan), pancuran kapit sendang (tiga bersaudara, tengahnya laki-laki) dan lain-lain

Kedua, golongan penyandang sukerto karena kelalaian perbuatan. Golongan ini ada 80 macam, beberapa di antaranya misalnya orang yang membuka jendela lebar-lebar pada waktu senja kala, orang yang membuat lumbung tanpa dasar, orang yang menyapu di waktu malam, orang yang membakar sampah di sembarang tempat, orang yang suka membuang sampah di longan (kolong bawah tempat tidur), orang yang menebang pohon sembarangan dan lain-lain.

Ketiga, golongan penyandang sukerto karena kecelakaan dalam pekerjaan, antara lain orang yang memecahkan pipisan (alas tumbuk waktu menumbuk jamu atau bumbu), orang yang mematahkan gandhik (penumbuk jamu), dan orang yang merobohkan dandang (tempat menanak nasi) pada waktu menanak nasi. ${ }^{10}$

Orang yang termasuk pada salah satu golongan dari tiga golongan itu termasuk penyandang sukerto atau pembawa sial, sehingga harus dihilangkan dengan cara diruwat. Jika tidak maka ia akan menjadi mangsanya Bathara Kala, sehingga hidupnya selalu diliputi kesialan. ${ }^{11}$

Sedangkan para tokoh spiritual kontemporer memberikan kategorisasi sengkala berbeda dengan yang telah dikenal selama ini, seperti sendang kapit pancuran (tiga anak yang nomor dua perempuan), kedhono kedhini (kembar laki-laki perempuan), kembang sepasang (dua anak perempuan semua) dan sebagainya. Para tokoh spiritual kontemporer setidaknya menyebutkan ada 29 kategori sengkala, yaitu: (a) Kebo kemali (sulit mendapat jodoh); (b). Babu laweyan (jika menikah, pasangan atau anak meninggal); (c). Jlomprong (sepanjang hidupnya terus menerus dirundung sakit); (d), Cluwak bodas (pasangan selalu bentrok, beda usia atau weton); (e) Sambit (lupa bayar hutang, hidup selalu susah dan usaha selalu gagal): (f) Cekal kendit (karier macet, jabatan tidak naik-naik); (g) Gotro pati (rezeki seret, kerja siang malam tidak ada hasil); (h). Kanthong bolong (hasil yang didapat selalu habis, boros); (i). Gendring bumi (usaha selalu gagal karena tanah yang ditempati wingit/ keramat/ tidak bagus); (j) Runing (sial atau sengsara karena dosa orang tua): (k). Bodes (sering mengingkari janji, hidup jadi apes); (l). Bandor sari (hidup selalu sial karena disumpah/dikutuk ibu); (m). Jeblak (hidup selalu sial karena disumpah/dikutuk

10 R. Harmanto Bratasiswara, "Sukerto", Bawwarna, Adat Tata Cara Jawa, Jakarta: Yayasan Suryasumirat, 2000), hal. 636.

11 Ibid. 467. 
ayah); (n). Cengis (sering difitnah orang); (o). Gabuk (sudah lama menikah tapi belum dikaruniai anak); (p). Cluring (hidup sial, usaha gagal, sering sakit); (q). Branjang sunu (sial karena makan makanan haram); (r). Srigunting (cinta selalu ditolak); (s). Blunuk Glontar (hidup sengsara karena menolak cinta); (t). Blorong (tak terasa kerja selalu berpindah-pindah); (u). Pantek jangkar (jiwa goncang karena salah mempelajari ilmu); (v). Gombak gimbal (sial karena penampilan, wajah, rambut diubah, misalnya operasi plastik, dll.); (w). Jebluk (sering mengalami kecelakaan); (x).Borong cokro (sial karena ingkar nadzar pada makam keramat); (y). Surengkala (di mana-mana dimusuhi orang, di rumah, di kantor, tempat kerja); (z). Cleret timbal (kesialan yang terjadi karena hukum karma).

Kategorisasi sengkala tersebut di atas adalah pengelompokan jenis-jenis kesialan yang dialami manusia karena melakukan perbuatan-perbuatan yang tidak baik. Makna yang terkandung dalam kategorisasi sengkala ini adalah supaya orang berhatihati terhadap tindak dan lakunya sehingga tidak tertimpa kesialan karena akibat dari perbuatannya. Kategorisasi tersebut sebagian di antaranya tampak mengingatkan bahwa perbuatan buruk terhadap orang lain (misalnya mengingkari janji, membunuh, mencelakakan orang lain, dan sebagainya) akan berdampak bagi dirinya dalam bentuk kesialan hidup.

\section{Pemaknaan Prosesi}

Prosesi ruwatan pakem asli biasanya terbagi pada tiga tahap, yaitu pendabuluan, pementasan wayang dan penutupan. Pertama, peserta ruwatan penyandang sukerto ruwatan dengan berpakaian putih-putih (terbuat dari kain mori/biasa untuk kafan jenazah) memasuki ruang pendapa tempat diselenggarakannya pentas wayang. Kedatangan sukerto dipimpin oleh seorang sesepub (pemuka adapt) disertai dua atau tiga gadis pembawa prasarana dupa, payung, pecut (cambuk/cemeti), dan pethuan (kayu pemukul kotak) dalang. Peserta upacara sungkem kepada kedua orang tuanya mohon doa restu. Kemudian sukerto menghadap dalang sejati meminta agar dalang berkenan meruwat. Setelah mendapat kepercayaan, dalang siaga dengan bersemadi yang intinya memohon izin kepada Tuhan Yang Maha Esa akan memulai acara ruwatan.

Kedua, pementasan wayang, dengan lakon Murwakala, yaitu asal-usul Bathara Kala. Pada akhir pergelaran, dalang menghentak peserta ruwatan supaya lari cepatcepat, sebagai gambaran agar tidak terkejar oleh Bathara Kala. Ketiga adalah penutupan. Setelah pementasan wayang selesai, dalang kemudian menyiramkan air kembang yang disebut banyu sangga dari sendang paruwatan ke kepala sukerto 
disertai mantra dan doa. Selanjutnya, dalang memotong ujung rambut sukerto disertai mantra dan doa. Terakhir, peserta ruwatan diminta berganti pakaian, pakaian putih-putih yang dikenakannya beserta potongan rambut diserahkan kepada pemuka adat (sesepub) untuk dilarung/dilabuh di laut lepas. ${ }^{12}$

Adapun prosesi ruwatan kontemporer juga melibatkan tiga unsur, yaitu mengapa seseorang tersebut harus diruwat, dalang atau tokoh spiritual yang memberikan penjelasan bagaimana mengatasi persoalan hidup, dan proses adjusment.

Penjelasan tentang persoalan hidup dan bagaimana menjalani hidup pada upacara ruwatan yang menggunakan wayang dengan lakon Murwakala sebagai sarana upacara dibeberkan oleh sang dalang dalam bentuk cerita (lakon wayang). Dalam upacara itu ada nilai pendidikan bukan saja kepada orang yang diruwat, tetapi juga kepada masyarakat yang menyaksikan pementasan wayang. Hal ini karena memang dalam sejarahnya wayang di Jawa digunakan sebagai media pendidikan masyarakat. Dibandingkan dengan prosesi ruwatan yang tidak menggunakan wayang sebagai sarana upacara, esensi ruwatan di mana ada nasihat oleh dalang, nasihat diberikan langsung oleh tokoh spiritual kepada manusia yang dianggap sial tersebut tentang mengapa terjadi persoalan hidup dan bagaimana mengatasi persoalan hidup tersebut. Hal ini dapat dilihat pada prosesi ruwatan bioenergi yang tahap-tahapnya adalah penjelasan mengenai mengapa muncul masalah hidup dan bagaimana mengatasi masalah hidup. ${ }^{13}$

Unsur berikutnya dari prosesi ruwatan adalah adjustment. Adjustment adalah saat penting bagi peserta ruwatan untuk melakukan kontemplasi, perenungan dan evaluasi diri, sehingga akan tercipta kedekatan pada Tuhan. Adjusment yang dalam ruwatan Bioenergi dilakukan dengan cara tokoh spiritual memasukkan energi positif, menyeimbangkan energi positif dan negatif dalam tubuh, dapat dimaknai saat di mana peserta ruwatan diminta melakukan evaluasi diri setelah sebelumnya menerima penjelasan tentang mengapa muncul persoalan hidup dan bagaimana mengatasi persoalan hidup tersebut. Jadi, ruwatan dengan pendekatan ini merupakan sarana pengolahan spiritual untuk memperoleh kebermaknaan hidup, memahami untuk apa hidup dan bagaimana hidup yang benar, sehingga dapat tercapai ketenangan batin. ${ }^{14}$

12 Ahmad Irfandi, Tradisi Ruwatan Santri di Bedingin, Kelurahan Tirtomoyo, Kecamatan Tirtomoyo, Kabupaten Wonogiri, Skripsi, Jurusan Perbandingan Agama Fakultas Ushuludin IAIN Sunan Kalijaga Yogyakarta, 2004, 40

13 Wawancara 16 Januari 2008.

14 Wawancara 29 Desember 2007. 


\section{Pemaknaan Sarana Upacara}

Pemaknaan dari aspek sarana upacara. Menurut Syaiful M. Maghsri, sarana upacara ruwatan merupakan pengejawantahan dari praktik sedekah (shadaqah) sehingga bentuk dan jumlah sebagaimana terdaftar dalam ruwatan Murwakala tidak mutlak. Lebih dari itu menurut. Misbah, seorang tokoh spiritual dan praktisi ruwatan di daerah Bantul, menyatakan bahwa sesungguhnya esensi ruwatan adalah sedekah dan pemberian peringatan kepada setiap manusia untuk tidak melupakan hubungannya dengan Tuhan. Menurutnya, manusia akan terbebas dari kesialan hidup manakala bersedia melakukan sedekah (representasi bablun min al-nas) dan membina hubungan baiknya dengan Tuhan (sebagai representasi bablun min Allah).

Meskipun jumlah dan bentuk sarana upacara (sesaji) tidak mutlak, namun penentuan jenis-jenis makanan tertentu dalam ruwatan menurut Muslikh memiliki makna simbolik tertentu. Beberapa sarana yang dimaknai secara simbolik antara lain sebagai berikut:

Pertama, tuwuhan, yang terdiri dari pisang raja setundun, yang sudah matang dan baik, yang ditebang dengan batangnya disertai cengkir gading (kelapa muda), pohon tebu dengan daunnya, daun beringin, daun elo, daun dadap serep, daun apaapa, daun alang-alang, daun meja, daun kara, dan daun kluwih yang semuanya itu diikat berdiri pada tiang pintu depan sekaligus juga berfungsi sebagai hiasan/ pajangan dan permohonan. Memiliki makna bahwa nikmat Tuhan yang berupa berbagai jenis tetumbuhan harus disyukuri dengan cara merawat dan memanfaatkannya sebaik-baiknya.

Kedua, api (batu arang) di dalam anglo, kipas beserta kemenyan (ratus wangi) yang akan dipergunakan Dalang selama pertunjukan. Memiliki makna sebagai sarana pengharum dan menciptakan efek kekhusyuan karena keharumannya yang khas.

Ketiga, kain mori putih kurang lebih panjangnya 3 meter, direntangkan dibawah debog (batang pisang) panggungan dari muka layar (kelir) sampai di belakang layar dan ditaburi bunga mawar dimuka kelir sebagai alas duduk Ki Dalang, sedangkan di belakang layar sebagai tempat duduk orang yang diruwat dengan memakai selimut kain mori putih. Memiliki makna mengingatkan peserta ruwatan dan semua orang yang menyaksikan prosesi ruwatan akan kebermaknaan hidup, bahwa hidup kelak akan mati dan tidak membawa apa- 
apa kecuali sehelai kain putih. Di samping itu juga memiliki makna hidup harus dibangun atas dasar kebersihan dan kesucian jiwa sebagaimana kain putih bersih yang tidak ternoda. ${ }^{15}$

Keempat, gawangan kelir bagian atas (kayu bambu yang merentang diatas layar) dihias dengan kain batik yang baru 5 (lima) buah, diantaranya kain sindur, kain bango tulak dan dilengkapi dengan padi segedeng (4 ikat pada sebelah menyebelah). Kelir adalah tempat digelarnya lakon wayang sebagai manifestasi dunia sebagai tempat berlangsungnya hidup manusia. Kelir digantung pada gawangan (bambu yang merintang) memiliki makna bahwa pergelaran kehidupan di jagad raya tidak bisa lepas dari ketergantungan terhadap kemurahan Tuhan. Oleh karena itu hidup harus diisi dengan lima laku ibadah (rukun Islam) yang dilambangkan dengan loma buah kain batik. Selain itu, tidak lupa bahwa hidup juga harus dihiasi dengan sedekah, yang dalam hal ini dilambangkan dengan padi segedeng 4 buah. Jumlah 4 gedeng (empat ikat) sebagai lambang bahwa perintah sedekah (zakat) dalam rukun Islam terdapat pada urutan keempat. ${ }^{16}$

Kelima, beras yang diolah dalam berbagai macam rasa makanan dan bentuk (nasi golong, wuduk, kuning, aneka bubur, dan sebagainya) memiliki makna bahwa apa yang harus dikeluarkan seseorang sebagai bentuk pemberian bukan hanya berbentuk zakat sebagaimana dilambangkan pada 4 gedeng padi di atas, tetapi juga sedekah aneka makanan dan hasil panen yang bisa jadi jumlahnya lebih banyak. Mengandung pelajaran bahwa setiap yang diberikan Tuhan harus disyukuri dan tidak untuk hanya dinikmati sendiri. ${ }^{17}$

Keenam, aneka jenis unggas antara lain burung dara satu pasang, ayam jawa sepasang, dan bebek sepasang. Memiliki makna bahwa binatang peliharaan yang diwakili berbagai jenis unggas (sebab tidak mungkin meletakkan binatang piaraan lain seperti sapi, kerbau atau kambing di dalam arena upacara) harus pula dizakatkan (disedekahkan) ketika dari pasangan-pasangan tersebut telah lahir dan berkembang menjadi banyak. ${ }^{18}$

Sarana-sarana upacara ruwatan detail tersebut tidak hanya memiliki makna tunggal sebagai anjuran untuk sedekah, namun juga memiliki nilai-nilai ajaran pendidikan kepada masyarakat bagaimana menjalani hidup secara benar.

15 Wawancara 19 Desember 2007.

16 Wawancara dengan Peruwat, KH Misbah tanggal 20 Februari 2008.

17 Ibid.

18 Ibid. 


\section{Pemaknaan Ruwatan Sebagai Ritual Keselamatan}

Pada pandangan kosmologi Jawa, dunia dilihat sebagai sebuah keteraturan yang setiap saat bisa terancam atau terganggu oleh adanya kekuatan jahat dari luar. Ancaman atau gangguan ini tercermin melalui konsep sukerto, yaitu kesialan atau kekotoran yang secara kodrati dibawa oleh individu sejak ia dilahirkan. Untuk membebaskan individu dari segala kekuatan jahat, ritual harus dihambat melalui ritual pemurnian diri. Ritual pemurnian diri ini biasanya dilaksanakan pada saat-saat krisis kehidupan individu, misalnya kelahiran, masa peralihan kanak-kanak menuju dewasa, perkawinan, dan kematian.

Seluruh ritual pemurnian diri tersebut dalam khazanah Jawa dikenal dengan upacara slametan. Secara umum, upacara slametan yang dilaksanakan masyarakat Jawa meliputi upacara pada siklus kehidupan dan siklus kematian. Siklus kehidupan antara lain tingkeban, ${ }^{19}$ brokohan, ${ }^{20}$ sepasaran, ${ }^{21}$ selapanan, ${ }^{22}$ telung lapanan, ${ }^{23}$ pitunglapanan, sunatan/tetakan, ${ }^{24}$ dan perkawinan. Sedangkan

19 Tingkeban adalah upacara yang dilakukan untuk menandai kehamilan anak pertama pada bulan ketujuh. Karena itu, upacara ini juga disebut dengan mitoni, dari kata pitu yang berarti tujuh. Meskipun disebut dengan istilah mitoni, tetapi pada kenyataannya upacara ini dilakukan pada hitungan kehamilan ke delapan bulan.

20 Brokohan adalah upacara slametan yang dilaksanakan pada saat kelahiran bayi. Pada upacara ini biasanya dilakukan dengan cara kenduri dengan mengundang para tetangga atau pada daerah tertentu dilakukan dengan cara membagikan bahan makanan mentah yang terdiri dari beras 1 gelas, gula jawa, kelapa, dan bumbu-bumbuan kepada tetangga.

21 Sepasaran adalah upacara slametan untuk menandai usia bayi menginjak 5 (lima) hari. Pada upacara ini sekaligus digunakan untuk memberikan nama kepada anak (bayi). Dari malam pertama kelahiran sampai malam kelima, biasanya para tetangga datang yang disebut dengan istilah jagong bayi untuk lek-lek'an (menahan tidur semalaman) untuk menemani orang tua yang baru melahirkan. Pada saat inilah biasanya diisi dengan berjudi kartu dengan alasan supaya mereka tahan tidak tidur

22 Selapanan adalah upacara slametan ketika bayi menginjak usia 35 hari. Pada usia ini rambut bayi dicukur habis, baik oleh dukun bayi maupun oleh orang tuanya sendiri. Pencukuran ini juga terkait dengan kepercayaan bahwa segala yang berasal dari dalam perut yang dibawa bayi lahir ke dunia harus berganti, termasuk rambut yang telah tumbuh sejak bayi di kandungan.

23 Telung lapanan adalah upacara kenduri ketika bayi menginjak usia 3 lapan (satu lapan $=35$ hari, 3 lapan $=105$ hari). Upacara ini adalah siklus ketiga dalam numerologi masyarakat Jawa. Satu siklus adalah 35 hari. Pitung lapanan adalah upacara ketika bayi menginjak usia 7 lapan (245 hari). Pada usia ini bayi mulai dikenalkan dengan tanah, sehingga dibarengi dengan upacara turun tanah (tedhak siten).

24 Sunatan/tetakan adalah ritual untuk menandai kedewasaan, yang bagi anak perempuan dinamai tetesan. Tradisi sunat diduga berasal dari praktik animisme-dinamisme di kalangan masyarakat Jawa. Indikasi mengenai hal ini dapat dicermati dalam cerita mitologi Jawa yang menggambarkan sunat sebagai ritual yang menyimbolkan pembebasan diri dari Betara Kala, dewa pemangsa manusia. ${ }^{25}$ Bagi masyarakat Jawa, sunat yang dilakukan dengan cara memotong penutup alat kelamin laki-laki, dimaknai sebagai sarana menghilangkan sukerta. 
upacara pada siklus kematian meliputi sripahan, telungdinanan, pitung dinan, patangpulub dina, nyatus (seratus hari), mendhak pisan (setahun), dan nyewu (seribu hari).

Upacara dalam siklus kehidupan berikutnya adalah pernikahan. Siklus ini dianggap sakral karena perkawinan merupakan batas kemandirian seseorang. Dengan perkawinan inilah manusia membentuk keluarga baru dan membentuk generasi baru.

Seluruh ritus inisisasi sebagaimana terurai di atas, baik terkait dengan siklus kehidupan maupun kematian, terbingkai dalam satu pandangan yaitu slametan. Seluruh upacara yang dilakukan dalam siklus hidupnya dimaksudkan untuk menjauhkan sejauh mungkin bahaya yang mungkin timbul dan memohon keselamatan dalam hidupnya.

Masyarakat Yogyakarta memiliki karakteristik yang disandarkan kepada nilai agama dalam hal ini Islam yang menjadi patokan utama dalam setiap perbuatan. Demikian pula dengan kegiatan slametan (ruwatan) ini pun tidak lepas dari unsur keagamaan. Karakteristik masyarakat Yogyakarta yang bersandar kepada nilai-nilai Islam inilah yang menjadi landasan ritual ruwatan sehingga tetap berjalan sampai sekarang. Jika diurai lebih jauh akan terlihat adanya sebuah motivasi dari masyarakat Yogyakarta dalam melakukan ritual slametan (ruwatan), yaitu motivasi beragama ${ }^{25}$ dan motivasi mempertahankan (nguri-uri) tradisi ${ }^{26}$

25 Keberadaan Motivasi beragama tidak bisa dilepaskan dari motif teogenetis yakni motif yang berasal dari interaksi antara manusia dengan TuhanNya seperti yang terwujud dalam ibadah dan normanorma agamanya. Realisasi dari motif teogenetis adalah keinginan untuk mengabdi kepada Tuhan Yang Maha Esa, keinginan untuk merealisasikan norma-norma agama menurut petunjuk Kitab Suci dan lainlain. Motivasi beragama sendiri adalah naluri manusia untuk selalu dekat, kembali dan meminta pertolongan kepada kekuatan Yang Maha Besar. Hal ini sejalan dengan fenomena yang terjadi di masyarakat itu sendiri. Hal ini mengindikasikan bahwa masyarakat mempercayai adanya sesuatu kekuatan Yang Maha Besar yang berada diluar kekuatan manusia itu sendiri. Mengurai tentang motivasi beragama, ritual buka luwur ini sejalan dengan konsep beragama dari Freud, yang menyatakan bahwa manusia beragama karena untuk menjaga kesusilaan serta tata tertib masyarakat. Menurut Freud, untuk menjaga atau menjamin berlangsungnya ketertiban dalam hidup menyangkut moral dan sosial, agama dapat dijadikan jembatan untuk bagaimana menciptakan ketertiban itu. Keberadaan agama bukan hanya ditujukan untuk kegiatan religius semata, melainkan juga kepada hal-hal yang bersifat sosial dan moral.

26 Motivasi ini menjadi faktor penting untuk menganalisa mengapa masyarakat Yogyakarta melakukan ritual ruwatan. Mencermati apa yang dilakukan masyarakat Yogyakarta saat melakukan ritual slametan, termasuk ruwatan, tentu dilandasi dari motif yang sama. Hal ini selaras dengan apa yang disampaikan oleh Gerungan yaitu dorongan atau motif bersama itu menjadi pengikat dan sebab utama terbentuknya kelompok sosial. Tanpa adanya motif yang sama antara sejumlah individu itu akan sukar terbentuk kelompok sosial yang khas. Lihat. Gerungan. Psikologi Sosial. (Bandung : PT Eresco, 1987). 
Berdasarkan beberapa responden yang peneliti temui dalam acara ruwatan dan yang pernah menjalani ruwatan, maka terdapat beberapa pandangan yang berbeda tentang makna ruwatan bagi masing masing mereka.

Pertama, mayoritas orang-orang yang pernah diruwat mengatakan bahwa ruwatan adalah media untuk membuang sial dari dalam diri mereka. Ruwatan merupakan bagian dari tradisi slametan di Jawa, sementara puncak dari acara slametan adalah ruwatan. Ruwatan berarti ritual keselamatan agar sial-sial yang melekat pada seseorang menjadi hilang, dan berubah menjadi keberuntungan. ${ }^{27}$

Kedua, ruwatan merupakan media untuk menselaraskan energi positif dan membuang energi negatif. Dalam ruwatan bioenergi, diyakini bahwa dalam hidup manusia banyak hal-hal yang menyebabkan energi positif tersumbat (blocking energy), karena sumpahan orang, bawaan, perasaan nerveous, dan perbuatan salah (dosa). Dengan adanya ruwatan, maka energi negatif tersebut dibuang dan energi positif yang tersumbat diselaraskan kembali ${ }^{28}$

Ketiga, ruwatan diartikan sebagai tradisi melestarikan budaya leluhur. Bagi kebanyakan orang, ruwatan diyakini sebagai tradisi asli masyarakat Jawa. Tradisi ini telah dilakukan turun temurun dari dahulu sampai saat ini. Selain berfungsi sebagai pembersih sukerto, ia juga berfungsi sebagai media sosialisasi (srawnng) antar sesama warga. Oleh karenanya dengan mereka masih mengikuti ruwatan, berarti mereka termasuk nguri-uri tradisi leluhur. ${ }^{29}$

Keempat, ruwatan berarti sedekah kepada sesama. Keyakinan ini diutarakan para ibu-ibu yang mengikuti ruwatan Kyai Asnuri di Bantul. Menurut mereka, pada dasarnya ruwatan yang mereka jalani itu adalah sedekah kepada sesama, sebab dalam ruwatan itu, mereka 'diwajibkan' untuk memberi makan 60 fakir miskin dan berdzikir dengan membaca bacaan tertentu. Mereka meyakini, setelah melaksanakan ruwatan tersebut, maka kesusahan hidup (keruwetan urip) bakal hilang dan sirna. ${ }^{30}$

Adapun ruwatan dilihat dari perspektif teologis, peneliti menemukan beberapa pendapat yang menarik. Pertama, bagi beberapa kalangan menilai bahwa ruwatan baik dalam bentuknya yang asli atau sudah terislamisasi adalah tradisi jawa (kejawen)

27 Hampir 80 persen memaknai ruwatan sebagai media untuk membuang sial dan keselametan. Wawancara dengan Ghufran, salah satu orang yang diruwat di Misbah, November 2007.

28 Wawancara dengan Asisten Saiful M. Maghsri peruwat bioenergi tanggal 17 Desember 2007.

29 Wawancara dengan Ngaliman, peserta ruwatan di pantai Samas Yogyakarta, tanggal 24 Desember 2007.

30 Wawancara dengan jamaah yang diruwat di Bantul Januari 2008. 
yang mempunyai nilai-nilai kemusyrikan (syirik), sehingga harus dihapus dan dihilangkan. Menurut golongan ini, peruwat dan orang yang diruwat adalah pelaku dosa besar, karena berbuat syirik, takhayul, bid'ah dan khurafat. Kepercayaan adanya Bhatara Kala, Sukerto, dan sesaji menurut mereka merupakan sumber kemusyrikan. ${ }^{31}$

Kedua, kelompok masyarakat yang menganggap bahwa ruwatan yang sudah diisi dengan nilai-nilai keislaman, seperti sedekah, pengajian, shalawatan, zikiran, manaqiban, dan khataman adalah perbuatan Islami. Artinya, meskipun namanya ruwatan, tetapi karena substansinya adalah zikir, shalawatan, pengajian, sedekahan, dan khataman, maka termasuk perbuatan Islami dan diperbolehkan, tidak ada unsur syirik, khurafat, dan takhayulnya. Sedangkan ruwatan dalam bentuk aslinya, yang masih mempercayai adanya Bhatara Kala dan sukerto bagi orang-orang tertentu tetap dianggap sebagai kemusyrikan. ${ }^{32}$

Ketiga, kelompok yang menganggap bahwa ruwatan dalam bentuk aslinya yang masih mementas wayang dengan judul Bhatara Kala sebagai bagian dari kekayaan budaya Jawa yang harus dilestarikan. Adanya kepercayaan terhadap Bhatara Kala dan sukerto bagi orang-orang tertentu, adalah cara sesepuh Jawa dahulu untuk mendidik masyarakat menjadi lebih baik dan beradab, tidak dianggap sebagai khurafat, bid'ah, syirik, dan takhayul. ${ }^{33}$

\section{Nilai Pendidikan dalam Ruwatan}

Dalam perspektif budaya, bertahannya tradisi ruwatan di tengah kehidupan masyarakat modern menunjukkan bahwa secara ia masih memiliki makna fungsional di tengah masyarakat. Konsep Spencer survival of the fittest yang dalam konteks ini artinya kebudayaan akan berjalan terus apabila mampu beradaptasi dengan lingkungan sekitarnya, dapat menjelaskan mengapa tradisi ruwatan hingga kini masih tetap hidup dan berjalan.

Teori fungsionalisme budaya menunjukkan bahwa suatu budaya akan tetap hidup di tengah masyarakat manakala ia memiliki fungsi yang bermakna bagi

31 Peneliti mengadakan dialog dengan IMM, FPI, HTI, dan PKS di beberapa masjid di Yogyakarta. Dalam dialog tersebut, peneliti pertama-tama memberikan keterangan tentang ruwatan dan perkembangannya sampai saat ini, karena banyak dari mereka tidak mengetaui secara detail tentang ruwatan, sebab-sebab dan pelaksanaannya.

32 Kesimpulan wawancara penulis dengan Tokoh NU, Ustadz/Kyai peruwat, dan santri-santri beberapa Pondok Pesantren di Yogya

33 Pendapat beberapa akademisi yang peneliti temui. 
masyarakat tersebut. Pengertian fungsi merujuk pada manfaat budaya bagi sesuatu. Oleh karena itu, menurut Malinowski, budaya memiliki hubungan yang erat dengan kebutuhan dasar dan kebutuhan sekunder manusia. Kedua kebutuhan tersebut berfungsi untuk mem-pertahankan kebudayaan dari kemusnahan.

Namun demikian menurut Radcliffe-Brown, kebutuhan manusia sebagai penopang keberadaan kebudayaan tersebut bukan didasarkan pada kebutuhan individual, melainkan kebutuhan secara sosial. Ia memelopori lahirnya teori fungsionalisme struktural yang menolak adanya istilah fungsi yang tidak dikaitkan dengan struktur sosial. Ia berpendapat bahwa budaya memiliki makna dan fungsi dalam kaitannya dengan kebutuhan dasar semua masyarakat yang disebut "coaptation". "Coaptation" adalah penyesuaian mutualistik kepentingan para anggota masyarakat.

Dalam konteks teori ini, ruwatan yang hingga kini masih terus berjalan karena dalam sistem sosial ia masih memiliki makna dan fungsi. Semua yang terlibat dalam tradisi tersebut, peserta dan keluarga yang diruwat, dalang yang meruwat, atau masyarakat sekitar ikut merasakan makna dari adanya tradisi tersebut.

Ada beberapa fungsi dari tradisi ruwatan yang berkembang di masyarakat Jawa, antara lain: (1) fungsi teologis; (2) fungsi filosifis; (3) fungsi sosioligis; dan (4) fungsi ekonomis. ${ }^{34}$ Masing-masing akan dielaborasi lebih jauh sebagai berikut:

\section{Nilai Pendidikan Teologis}

Dalam perspektif teologis, ruwatan mengandung fungsi sebagai upaya mendekatkan diri pada Tuhan. Ruwatan adalah media pendidikan bagi manusia bahwa penyerahan akhir dari setiap persoalan yang dihadapi manusia berada di tangan Tuhan. Ruwatan adalah salah satu ritual masyarakat Jawa dalam berhubungan dengan realitas transenden, mengevaluasi kondisi diri, memeriksa aktivitas yang dilakukan, dan memohon keselamatan kepada Tuhan untuk dihindarkan dari malapetaka dan kesulitan hidup.

Mitos Bathara Kala dalam tradisi ruwatan adalah manifestasi dari gangguangangguan yang mungkin timbul dalam kehidupan manusia di luar kesanggupannya untuk mengatasi masalah yang dihadapi tersebut. Dalam kondisi demikian, seseorang diarahkan untuk meminta bantuan kepada satu kekuatan tanpa batas, yaitu Tuhan.

34 Disimpulkan dari hasil wawancara dengan beberapa peruwat dan orang-orang yang diruwat. 
Pandangan makrokosmos masyarakat Jawa melihat bahwa wujud alam semesta terbagi dalam tiga bagian: alam atas, alam tengah, dan alam bawah. Alam atas dipercayai sebagai tempat tinggal Tuhan yang Maha Kuasa, roh-roh suci, dewa-dewi; makhluk ghaib yang berperangai baik yang selalu membantu manusia. Alam tengah adalah alam nyata yang dipakai sebagai tempat tinggal manusia, hewan dan berbagai makhluk fisik lainnya. Sedangkan alam bawah dipercaya sebagai tempat tinggal roh-roh jahat, hantu yang mengganggu kehidupan manusia, kekuatan-kekuatan negatif yang dapat mencelakakan manusia. Kehidupan manusia berada wilayah tarik menarik antara pengaruh kekuatan Alam Atas dan Alam Bawah. Dalam pandangan makrokosmos ini, ruwatan merupakan sarana ritual memohon perlindungan kepada Tuhan sebagai representasi alam atas untuk dihindarkan dari gangguan roh-roh jahat sebagai representasi alam bawah. ${ }^{35}$

\section{Nilai Pendidikan Filosofis}

Dalam perspektif filosofis, pertanyaan yang dikembangkan adalah mengapa ruwatan perlu ada, bagaimana ia ada, dan untuk apa ia ada. Pertanyaan-pertanyaan tersebut akan mengurai fungsi ruwatan secara filosofis, sehingga ia masih tetap bertahan hingga kini.

Pada awalnya, keberadaan ruwatan merupakan salah satu cara para pujangga Jawa mendidik masyarakat Jawa bagaimana menyikapi persoalan hidup dan mengisi hidup dengan benar. Wayang sebagai media upacara ruwatan juga tidak lepas dari nilai pendidikan ini, karena memang dalam sejarahnya wayang selain berfungsi sebagai hiburan, juga sebagai sarana pendidikan masyarakat yang dikemas dalam bentuk cerita. Berbagai sarana yang harus disediakan untuk upacara ruwatan secara filosofis juga mengandung nilai edukatif, selain mendidik orang untuk bersedekah, juga mengajari bagaimana menafsirkan simbol-simbol yang digunakan dalam upacara tersebut. ${ }^{36}$

\section{Nilai Pendidikan Sosial dan Budaya}

Fungsi sosiologis ruwatan dapat dilihat dari dua aspek, yakni fungsi sebagai pembangun relasi antar individu dan kelompok dalam kehidupan sosial dan fungsi budaya. Pertama, ruwatan berfungsi sebagai sarana membangun hubungan yang baik antara individu dalam satu kelompok sosial. Salah satu inti ajaran ruwatan adalah ajaran bersedekah, saling berbagi kepada sesama yang membutuhkan. Dalam

35 Wawancara dengan Asisten Saiful M. Maghsri tanggal 20 Desember 2007.

36 Wawancara dengan Dalang 25 Desember 2007. 
konteks ini, ruwatan memiliki fungsi sebagai perekat sosial, pembangun relasi antar individu dalam satu komunitas karena sedekah sebagai salah satu inti prosesi ruwatan merupakan sarana yang efektif untuk menjalankan fungsi ini. Kedua, fungsi budaya. Dari sisi fungsi budaya, ruwatan yang masih berkembang merupakan pelestarian budaya. Dalam konteks pelestarian budaya, ruwatan dipandang sebagai satu aset sosial dan aset ekonomi.

\section{E. Penutup}

Ruwatan adalah upacara yang dilakukan seseorang untuk membebaskan (sukerto) dari nasib buruk dan ancaman malapetaka. Sukerto atau sesuker (rereged) adalah kelemahan tertentu yang dipercaya dapat mengundang datangnya malapetaka yang mengancam keberadaan dan kebahagiaan. Praktik ruwatan yang menyertakan kepercayaan adanya kelemahan (sukerto) pada diri manusia, dan juga kepercayaan adanya Bathara Kala sebagai sumber dan pemberi malapetaka, secara sekilas seakan bertentangan dengan tradisi Islam (musyrik) dan praktik yang tanpa makna. Namun ketika ditelaah lebih jauh, ternyata praktik ruwatan mempunyai nilai edukatif yang tinggi bagi masyarakat, terutama pendidikan moral.

Adapun nilai-nilai pendidikan yang terdapat dalam tradisi ruwatan adalah sebagai berikut yaitu nilai pendidikan teologis, nilai pendidikan filosofis, dan nilai pendidikan sosial dan budaya. Intinya ruwatan menjadi media untuk mendidik masyarakat agar mempunyai kesadaran kolektif, berbuat baik, bersedekah, memperhatikan kebersihan dan kelestarian lingkungan.

\section{DAFTAR PUSTAKA}

Abdullah, Azyumardi Azra dan Irwan. 2002. "Islam dan Akomodasi Kultural”, dalam Taufik Abdullah, Ensiklopedi Tematis Dunia Islam. Jakarta: PT. Ichtiar baru Van Hoeve.

Abshar-Abdalla, Ulil. 2003. 'Menimbang Islam Pribumi,' dalam Tashwirul Afkar Edisi No. 14.

Al Jauziyah, Ibnul Qoyyim. T.t. Athiflu Wa Abkamubu. Beirut: Dar al-Fikr.

Amir, Hasyim. 1994. Nilai-Nilai Etis dalam Wayang. Jakarta: Pustaka Sinar Harapan. Bahtiar, Amsal. 1997. Filsafat Agama I. Jakarta: Logis Wacana Ilmu. 
Benda, H.J. 1983. The Crescent and the Rising Sun, Indonesian Islam under the Japanese Occupation, 1942 - 1945. Leiden: KITLV.

Bratasiswara, R. Harmanto. 2000. Bawwarna; Adat Tata Cara Jawa. Jakarta: Yayasan Suryasumirat.

Chodjim, Achmad. 2004. Mistik dan Makrifat Sunan Kalijaga. Yogyakarta: Serambi.

Djamil, Abdul dkk. 2000. Islam dan Kebudayaan Jawa. Yogyakarta: Gama Media.

Djamil, Abdul. 2000, "Islam Lokal, dalam http://www.suaramerdeka.com.

Endraswara, Suwardi. 2003. Budi Pekerti. Yogyakarta: Hanindita.

Ensiklopedia Indonesia, N-Z Bandung's Graven Hage, W. Van Hoeve, t.th

Fakhry, Majid. 2001. Sejarah Filsafat Islam: Sebuah Peta Kronologis. Bandung: Mizan.

Geertz, Clifford. 1976. The Religion of Java. Chicago \& London: University of Chicago Press.

Gerungan. 1987. Psikologi Sosial. Bandung: PT Eresco.

Gonggong, Anhar (peny.). 1993. Sejarah Kebudayaan Jawa. Jakarta: Departemen Pendidikan dan Kebudayaan, Direktorat Jenderal Kebudayaan, Direktorat Sejarah dan Nilai Tradisional, Proyek Inventarisasi dan Dokumentasi Sejarah Nasional.

Hasjmi, A. 1989. Sejarah Masuk dan Berkembangnya Islam di Indonesia, Kumpulan Prasaran pada Seminar di Aceh. Bandung: PT. Al Ma’arif.

Imaduddin, M. dkk. 2003. "Islam Pribumi: Mencari Wajah Islam Indonesia," dalam Tashwirul Afkar Edisi No. 14.

Imarah, Muhammad. 1996. Al Islam wa al 'Urubah. Kahirah: Al Haihal Al Mashriyyah Al 'Ammah Lil Kitab.

Irfandi, Ahmad. 2004. "Tradisi Ruwatan Santri di Bedingin, Kelurahan Tirtomoyo, Kecamatan Tirtomoyo, Kabupaten Wonogiri”. Skripsi. Yogyakarta: Jurusan Perbandingan Agama Fakultas Ushuludin IAIN Sunan Kalijaga.

Khaldun, Ibnu. 1989. Muqaddimah Ibnu Khaldun. Beirut: Dar al-Fikr.

Koentjaraningrat. 1984. Kebudayaan Jawa. Jakarta: Balai Pustaka.

Kompas. 2003. 17 April. 
KS, Muslich. 2007. Pandaming Kalbu dalam Islam dan Pesan Moral Budaya Jawa. Yogyakarta: Global Pustaka Utama.

Kuntowijoyo. 1991. Paradigma Islam: Interpretasi untuk Aksi. Bandung: Mizan.

Mardiwarsito. 1978. Kamus Jawa Kuno-Indonesia. Ende Flores: Nusa Indah.

Meteor Jogja, Harian Kriminalitas dan Metafisika. 2006. 9 Februari.

OC, D. Hendropuspito. 1994. Sosiologi Agama. Jakarta: BPK Gunung Mulia.

Purwadi. 2003. Sunan Kalijaga, Sintesis Ajaran Walisanga dan Syaikh Siti Jenar. Yogyakarta: Persada.

2005. Filsafat Jawa. Yogyakarta: Media Abadi.

Yogyakarta: Pustaka Pelajar.

Qadir, C.A. 2002. Filsafat dan Ilmu Pengetabuan dalam Islam. Jakarta: Yayasan Obor. Qardhawi, Yusuf. 1993. Madkhal Li Al Dirasah al Islamiyyah. Beirut: Dar al-Fikr. Republika. 2004. Kamis, 30 Desember.

Romli, Inajati Adrisijanti. 1991. "Makam-Makam Kesultanan dan Para Wali Penyebar Islam di Pulau Jawa", dalam Aspek-Aspek, Arkeologi Indonesia, No. 12. Jakarta: Pusat Penelitian Arkeologi Nasional.

. 1997. "Islam dan Kebudayaan Jawa", dalam Cinandi. Yogyakarta: Panitia Lustrum VII Jurusan Arkeologi UGM.

Roy, Muhammad. 2004. Ushul Fiqh Maďhab Aristoteles: Pelacakan Logika Aristoteles dalam Qiyas Ushul Fiqh. Yogyakarta: Safirian Insania Press.

Said, Hamka dan Muhammad. 1963. "Sejarah Masukknya Islam ke Indonesia”, Makalah Seminar, Medan.

Salam, Solichin. 1997. Kudus Purbakala dan Perjuangan Islam. Surabaya: Cahaya.

Satoto, Budiono Heru. 1997. Simbolisme dalam Budaya Jawa. Yogyakarta: PT. Hanindita.

Shadily, Hasan. 1963. Sosiologi untuk Masyarakat Indonesia. Jakarta: PT. Pembangunan.

Simuh. 2000. "Islam dan Budaya Jawa", Makalah, disampaikan pada "Seminar Pengaruh Islam Terhadap Budaya Jawa, 31 Nopember. 
. 2004. "Interaksi Islam dan Budaya Jawa", dalam Anasom [Ed.], Merumuskan Kembali Interelasi Islam - Jawa. Yogyakarta: Gama Media.

Suhardja, Dradjat. 2004. Mengaji Ilmu Lingkungan Kraton. Yogyakarta : Safiria Insania Press.

Sunyoto, Agus. 2003. Suluk Abdul Jalil: Perjalanan Ruhani Syaikh Siti Jenar. Yogyakarta: LKiS.

2004. Sunan Ampel Raja Surabaya, Dinamika Perjuangan Dakwah Islam di Jawa Abad XIV - XV M. Surabaya: Diantama berkerja sama dengan Lembaga Pengkajian Bahasa Arab Masjid Agung Sunan Ampel.

Surakhmad, Winarno. 1991. Pengantar Penelitian Ilmiah, Dasar Metode Teknis. Bandung: Tarsito.

Suryo, Djoko. 2000. “Tradisi Santri dalam HIstoriografi Jawa”, Makalah, disampaikan pada Seminar "Pengaruh Islam Terhadap Budaya Jawa, 31 Nopember.

Tim Penulis Sena Wangi. 1999. Ensiklopedi Wayang Indonesia. Jakarta: Senawangi. Tjandrasasmita, Uka. 2002. "Kedatangan dan Penyebaran Islam", dalam Taufik Abdullah, Ensiklopedi Tematis Dunia Islam. Jakarta: PT. Ichtiar baru Van Hoeve.

Wahid, Abdurrahman. 2001, Pergulatan Negara, Agama, dan Kebudayaan. Jakarta: Desantara.

Walujo, Kanti. 2000. Dunia Wayang, Nilai Estetis, Sakralitas dan Ajaran Hidup. Yogyakarta: Pustaka Pelajar.

Yatim, Badri. 2002. "Dari Mekah ke Madinah", dalam Taufik Abdullah, Ensiklopedi Tematis Dunia Islam. Jakarta: PT. Ichtiar baru Van Hoeve.

Zetmulder. 1982. Kalangwan. Jakarta: Penerbit Djambatan. 